\title{
GENERAL FLORISTIC SURVEY OF GRAND TETON NATIONAL PARK AND VICINITY, WYOMING
}

\author{
RONALD HARTMAN $\downarrow$ DAVE SCOTT \\ ROCKY MOUNTAIN HERBARIUM \ UNIVERSITY OF WYOMING \ LARAMIE
}

\section{$\downarrow \quad$ INTRODUCTION}

A broad-scale floristic inventory of all vascular plants was proposed for Grand Teton National Park and the John D. Rockefeller Jr. Memorial Parkway (JDR) primarily to document the extant flora in remote backcountry areas. The Teton Mountains are floristically important because of the unique habitats which they contain, because their relatively undisturbed (human disturbance) condition, and because of their proximity to the Yellowstone Plateau, a floristically unique area of Wyoming. Many studies have explored these lands for purposes of vegetation characterization (Cogan et al. 2005, McCloskey 2006) though an explicit and complete plant inventory parkwide had never been undertaken.

We first examined the vascular plant specimen holdings of the Rocky Mountain Herbarium (RM) to assess spatially where the previous records were obtained. It was observed that some townships (36 square miles) within the Park had as little as 8 voucher collections and one partial township ( 8 square miles) had zero vouchers. This information again reinforced our focus on backcountry areas; we also chose to collect in frontcountry areas to document introduced plants and for sampling completeness. This report serves as the final product of this project yet the full species list is not included for space limitations.

\section{$\downarrow$ METHODS}

A landscape-scale floristic inventory was conducted on Grand Teton National Park and the JDR, wholly within Teton County, Wyoming. The collection localities were often reached by hiking long distances from the trailhead. When the desired habitat was reached, geographic coordinates were recorded, then all vascular plants exhibiting fruits or flowers were collected. From such a starting point, we continued along the collecting path and collecting was designed to encompass the bulk of nearby plant habitats, often with a distant plant habitat as target. Target habitats were often chosen because of the high likelihood of rare or unusual plants they might contain (Hartman and Nelson 2005). Examples of target habitats in the project area were: alpine elevations, limestone substrates, neoglacial deposits, montane ponds, thermal areas, and wetlands. In the meander search/collecting path method described here, the highest number habitats are thought to be encountered for the unit time in the field.

About half of the collecting paths were in frontcountry areas or along trails. When covering these areas, an ample representation of introduced plants along with the native flora was expected. Nearly all of the rest of the collecting routes were off-trail in areas infrequently or never visited by humans. 
Collected plants were pressed and dried for scientific vouchering and they were identified by Dave Scott at the Rocky Mountain Herbarium, Laramie, WY. The herbarium environment is conducive to correct identifications due to the availability of authenticated specimens and other taxonomic resources easily referenced there. Identifications for the families Apiaceae and Caryophyllaceae were verified by Ron Hartman, specialist in both families for western North American taxa. B. Ernie Nelson, RM manager verified all other important collections: 1) Wyoming Natural Diversity Database (WYNDD) sensitive species, 2) Teton County records (plants first documented in Teton County) and, 3) some taxa first documented in the Park under this project.

Each voucher includes associated scientific name and authority, plant habitat information, collector, date, (often) GPS coordinates, elevation, and land ownership fields. This information was produced for specimen labels in a Microsoft Access database and was conveyed to Grand Teton National Park, Science and Resource Management personnel upon completion.

\section{$\downarrow \quad$ RESULTS}

Overall, floristic diversity was captured by the high number of specimens collected across the Park and JDR in two field seasons during summers 2006 and 2007. Figure 1 illustrates the spatial extent of collections by displaying the 277 collection localities. The total number of herbarium quality collections was 5851 vouchers. As expected, multiple collections of certain taxa were obtained and for these common plants a better understanding of their distribution was attained. The total number of species documented was 869, and 912 taxa (includes subspecies/variety taxonomic level) were documented. A full set of vouchers now reside at the RM (on loan from the Park) for all taxa reported here. The USDA PLANTS database (Version 15 May 2008) was considered the taxonomic authority for the species list. As well as a full list of vascular plants collected, new populations of WYNDD taxa were revealed and newly documented WYNDD taxa previously unknown to the area were collected. Likewise, contributions of this study are 20 County records, and introduced species locations. A synopsis of these results follows.

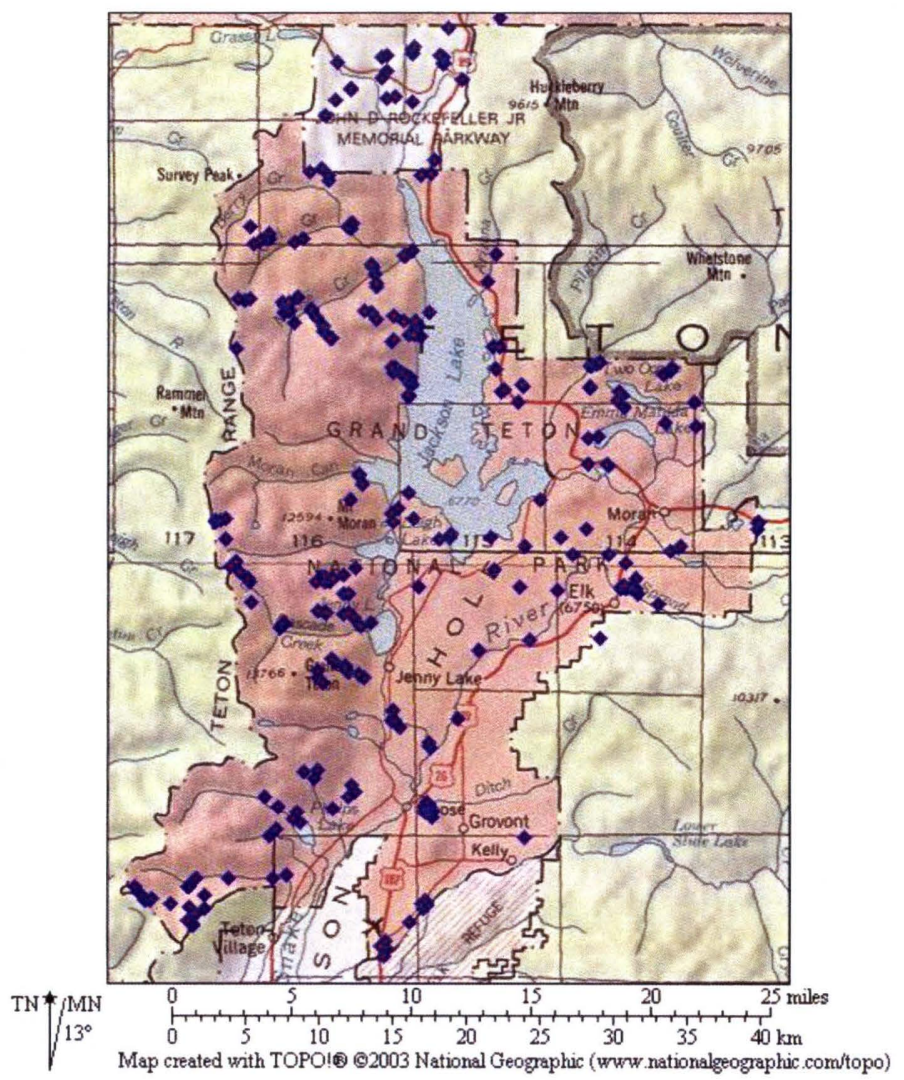

Figure 1. Collection localities from the floristic inventory of Grand Teton National Park and John D. Rockefeller Jr. Memorial Parkway. The diamond symbol indicates each locality; 277 unique GPS coordinates were recorded. Taxa either currently or historically tracked by WYNDD numbered 44 species (Table 1). The 2003 list was considered because it represented WYNDD species of conservation concern at the time we started this project. Further, the 2007 WYNDD list was produced using data from this project prior to its publication. Subsequently, it is useful to take into account both lists as they provide a context to judge species trajectories through time. Nine WYNDD taxa we collected were previously unknown to Grand Teton National Park or the JDR (Table 1). 


\begin{tabular}{|c|c|c|c|c|c|}
\hline Scientific name & Common name & 2003 list & 2007 list & $\begin{array}{l}\text { 2007 Heritage } \\
\text { Rank }\end{array}$ & $\begin{array}{l}\text { New to } \\
\text { GRTE }\end{array}$ \\
\hline Agrostis mertensii & Northern bentgrass & listed & listed & $\mathrm{G} 5 / \mathrm{S} 2$ & $\mathrm{x}$ \\
\hline Antennaria aromatica & Aromatic pussytoes & $\begin{array}{l}\text { potential } \\
\text { concern }\end{array}$ & $\begin{array}{l}\text { potential } \\
\text { concern }\end{array}$ & G3G4/S3 & \\
\hline Aquilegia formosa & Crimson columbine & listed & listed & G5T5/SH & \\
\hline Aspidotis densa & Pod-fern & listed & listed & G5/S1 & \\
\hline $\begin{array}{l}\text { Asplenium trichomanes- } \\
\text { ramosum }\end{array}$ & Green spleenwort & listed & listed & G4S2 & \\
\hline Astragalus shultziorum & Shultz's milkvetch & $\begin{array}{l}\text { potential } \\
\text { concern }\end{array}$ & $\begin{array}{l}\text { potential } \\
\text { concern }\end{array}$ & G3S3 & \\
\hline Astragalus terminalis & Railhead milkvetch & listed & listed & G3/S1 & \\
\hline Athyrium americanum & American alpine lady fern & listed & listed & G4G5T4T5/S2 & \\
\hline Botrychium minganense & Mingan moonwort & listed & listed & G4/S1 & $\mathrm{x}$ \\
\hline Botrychium multifidum & Leathery grape-fern & listed & deleted & G5/S3 & \\
\hline Carex cusickii & Cusick's sedge & listed & listed & G5/S2 & \\
\hline Carex echinata ssp. echinata & Little prickly sedge & listed & listed & G5/S1 & \\
\hline $\begin{array}{l}\text { Carex incurviformis var. } \\
\text { danaensis }\end{array}$ & Incurved sedge & listed & listed & G4G5T3/S2 & $\mathrm{x}$ \\
\hline Carex leptalea & Bristly-stalk sedge & listed & listed & G5/S2 & \\
\hline Carex limosa & Mud sedge & listed & listed & G5/S2 & $\mathrm{x}$ \\
\hline Carex livida & Livid sedge & listed & listed & G5/S2 & $\mathrm{x}$ \\
\hline Carex proposita & Smoky Mountain Sedge & listed & listed & G4/SH & $\mathrm{x}$ \\
\hline $\begin{array}{l}\text { Descurainia pinnata ssp. } \\
\text { paysonii }\end{array}$ & Payson's tansymustard & listed & listed & G5T3?/S2 & \\
\hline Draba crassa & Thick-leaf Whitlow-grass & $\begin{array}{l}\text { potential } \\
\text { concern }\end{array}$ & $\begin{array}{l}\text { potential } \\
\text { concern }\end{array}$ & G3/S3 & \\
\hline $\begin{array}{l}\text { Draba fladnizensis var. } \\
\text { pattersonii }\end{array}$ & White arctic whitlow-grass & listed & listed & G4T2T3/S2 & \\
\hline Drosera anglica & English sundew & listed & listed & G5/S2 & \\
\hline $\begin{array}{l}\text { Eleocharis flavescens var. } \\
\text { thermalis }\end{array}$ & Warm springs spikerush & listed & listed & G5T2T3Q/S2 & \\
\hline Gentianopsis simplex & Hiker's gentian & listed & listed & G5/S1 & $\mathrm{x}$ \\
\hline Gymnocarpium disjunctum & Oak fern & listed & listed & G5/S2 & \\
\hline Huperzia haleakalae & Fir clubmoss & listed & listed & G4G5/S1 & \\
\hline Juncus filiformis & Thread rush & listed & listed & G5/S2 & \\
\hline Kelloggia galioides & Milk kelloggia & listed & listed & G5/S1 & \\
\hline $\begin{array}{l}\text { Lesquerella carinata var. } \\
\text { carinata }\end{array}$ & Keeled bladderpod & listed & listed & G3G4T3T4/S2 & \\
\hline Lesquerella paysonii & Payson's bladderpod & $\begin{array}{l}\text { potential } \\
\text { concern }\end{array}$ & $\begin{array}{l}\text { potential } \\
\text { concern }\end{array}$ & $\mathrm{G} 3 / \mathrm{S} 3$ & \\
\hline Listera convallarioides & Broad-leaved twayblade & listed & listed & G5/S2 & \\
\hline $\begin{array}{l}\text { Luzula glabrata var. } \\
\text { hitchcockii }\end{array}$ & Smooth wood-rush & listed & listed & G5T4/S1 & \\
\hline $\begin{array}{l}\text { Minuartia macrantha } \\
\text { [Minuartia filiorum] }\end{array}$ & House's stitchwort & listed & listed & G3G4/S1 & \\
\hline Myriophyllum verticillatum & Whorled water-milfoil & listed & listed & G5/S1 & $\mathrm{x}$ \\
\hline Parnassia kotzebuei & Kotzebuei grass-of-parnassus & listed & listed & $\mathrm{G} 5 / \mathrm{S} 2$ & \\
\hline Porterella carnosula & Western porterella & listed & listed & G4S1 & \\
\hline Sanicula graveolens & Sierra sanicle & listed & listed & G4G5/S2 & $\mathrm{x}$ \\
\hline Scirpus americanus & American bulrush & listed & listed & G5/S2 & \\
\hline Spirodela polyrhiza & Common water-flaxseed & listed & listed & G5/S1 & \\
\hline Stellaria crispa & Crimped stitchwort & listed & listed & G5/S1 & \\
\hline Utricularia minor & Lesser bladderwort & listed & listed & G5/S2 & \\
\hline Viola orbiculata & Western rough-leaved violet & listed & deleted & G5/S2 & \\
\hline Viola renifolia & Kidney leaf white violet & listed & listed & G5T5/S1 & \\
\hline Xerophyllum tenax & Western beargrass & listed & listed & G4G5/S1 & \\
\hline
\end{tabular}

Table 1. Sensitive taxa tracked by Wyoming Natural Diversity Database (WYNDD) and encountered during the inventory. Taxa shown according to WYNDD Wyoming Plant and Animal Species of Concern list 2003 version (Keinath, et al.) and 2007 Wyoming Plant Species of Concern list (Heidel 2007). 
Heritage Rank: WYNDD uses a standardized ranking system originally developed by The Nature Conservancy and its network of natural heritage programs (now coordinated by NatureServe [Arlington Virginia]) to indicate the probability of extinction, at both the global and state scales, of each plant and animal taxon. The following letters denote the spatial scale at which a taxon's status is scored:

$\mathbf{G}=$ Global rank: refers to the range-wide probability of extinction for a species

$\mathbf{T}=$ Trinomial rank: refers to the range-wide probability of extinction for a subspecies or variety

$\mathbf{S}=$ State rank: refers to probability of extinction from WY for a given taxon

These letters are each followed by a numeric, 1-5 score:

$\mathbf{1}=$ Critically imperiled because of extreme rarity (often $<5$ extant occurrences) or because some factor makes it highly vulnerable to extinction

$\mathbf{2}=$ Imperiled because of rarity (often 6-20 extant occurrences) or because of factors making it vulnerable to extinction

$\mathbf{3}=$ Rare or local throughout its range or found locally in a restricted range (often 21-100 known occurrences)

$\mathbf{4}=$ Apparently secure, although it may be quite rare in parts of its range, especially at the periphery

$\mathbf{5}=$ Demonstrably secure, although it may be rare in parts of its range, especially at the periphery

Some 81 taxa were collected on Grand Teton National park or the JDR which had not been previously documented.

This number includes the 9 WYNDD taxa mentioned above.

\section{$\downarrow$ DISCUSSION}

Two State records were collected in Grand Teton National Park. One, Achillea ptarmica is an introduced cultivar found to be naturalized in irrigation ditches near the historical Whitegrass Ranch. These plants were found to be flowering in late summer (August) at only this single locality thus we recommended here that a more complete inventory of this species be carried out. This rhizomatous perennial indeed has potential to spread from the current habitat of irrigation ditches to natural riparian corridors.

A second species new to Wyoming is the native sedge, Carex atrosquama. It is not surprising to document this species because it has been collected in nearby Colorado, Idaho, Montana, and Utah. Western Wyoming, however, may be the eastern extent of this species' distribution. Habitat recorded for Carex atrosquama was a montane area in the lower South Fork of Granite Canyon. Though this is the first collection of this species in Wyoming, it may be more common than the lack of records indicate because sedges are often cryptic and repeatedly get overlooked.

Introduced plants comprised only $7.5 \%$ of the total taxa documented here. In fact most were already known from the Park, but we assert 9 new introduced taxa now documented due to this inventory. A few insidious species were: Linaria vulgaris, Cirsium arvense, and Carduus nutans, where the first two were often observed in montane backcountry areas. These two species probably represent the most invasive weeds in backcountry areas. Less invasive introduced taxa commonly observed in backcountry areas were: Poa annua on trails, Crepis tectorum in scoured streambeds, moist meadows or burned areas. Also, Phleum pratense was seen in a diversity of backcountry habitats and Cerastium fontanum ssp. vulgare was collected in remote riparian areas.

A biodiversity hotspot was observed near the Huckleberry Hot Springs in the JDR. Several native plants were exclusively collected there, though a significant suite of introduced plants were also found at that locality. The introduced species appear to be associated with walking paths adjacent the springs and should be controlled in the future, given their proximity to the thermal springs habitat that does provide for native biodiversity. Related to this topic is the exceptional native plant diversity of the JDR wetlands in general. Several species were only collected in these habitats and these areas display affinities to the flora of the Yellowstone Plateau (to the north), which is different than much of the flora of Grand Teton National Park.

\section{$\downarrow$ LITERATURE CITED}

Cogan, D. and K. Varga, G. Kittel, K. McCloskey, D. Abendroth, J. Gremer, C. Bolen. 2005. Grand Teton National Park 2002-2005 vegetation mapping project final report. NPS-USGS Vegetation Mapping Program. U.S. Department of the Interior, Denver, CO. 
Hartman, R.L. and B.E. Nelson 2005. General information for floristics proposals. Online:http://www.rmh.uwyo.edu/resear $\mathrm{ch} /$ GeneralInformationforFloristicsPropo sals.pdf

Heidel, B. 2007. Wyoming plant species of concern list. Unpublished document. Wyoming Natural Diversity Database, Laramie, WY.

Keinath, D., and B. Heidel, G. Beauvais. 2003. Wyoming plant and animal species of concern. Unpublished document. Wyoming Natural Diversity Database, Laramie, WY.

McCloskey, K. J. 2006. Vascular plant species richness and distribution in a heterogeneous landscape. $\mathrm{Ph} . \mathrm{D}$ dissertation, Utah State University, Logan. 